\title{
Eurolntervention
}

\section{The twelve-month outcomes of a biolimus eluting stent with a biodegradable polymer compared with a sirolimus eluting stent with a durable polymer}

Scot Garg ${ }^{1}$, MB ChB, MRCP; Giovanna Sarno¹, MD, PhD; Patrick W. Serruys ${ }^{1 *}$, MD, PhD; Ton de Vries², MSc; Pawel Buszman ${ }^{3}$, MD, PhD; Axel Linke ${ }^{4}, \mathrm{MD}, \mathrm{PhD}$; Thomas Ischinger ${ }^{5}$, MD, PhD; Volker Klauss ${ }^{6}$, MD, PhD; Franz Eberli7 , MD; Roberto Corti ${ }^{8}, \mathrm{MD}^{7}$ William Wijns ${ }^{9}, \mathrm{MD}, \mathrm{PhD}$; Marie-Claude Morice ${ }^{10}$, MD; Carlo Di Mario ${ }^{11}$, MD, PhD; Robert Jan van Geuns ${ }^{1}$, MD, PhD; Pedro Eerdmans ${ }^{12}$, MD, PhD; GerritAnne van Es ${ }^{2}$, PhD; Bernhard Meier ${ }^{13}$, MD; Peter Jüni ${ }^{14,15}$, MD; Stephan Windecker ${ }^{13,14}$, MD, PhD

1. Department of Interventional Cardiology, Erasmus MC, Rotterdam, The Netherlands; 2. Cardialysis B.V, Rotterdam, The Netherlands; 3. Medical University of Silesia, Katowice, Poland; 4. Herzzentrum Leipzig, Leipzig, Germany; 5. Department of Cardiology, Hospital Bogenhausen, Munich, Germany; 6. Department of Cardiology, University Hospital Munich (Innenstadt), Munich, Germany; 7. Currently working at department of Cardiology, Triemli Spital, Zurich, Switzerland; 8. Department of Cardiology, University Hospital Zurich, Zurich, Switzerland; 9. Department of Cardiology, Onze Lieve Vrouw Ziekenhuis, Aalst, Belgium;

10. Institut Jacques Cartier Massy, France; 11. Department of Cardiology, Royal Brompton Hospital, London, United Kingdom; 12. Biosensors Europe SA, Morges, Switzerland; 13. Department of Cardiology, University Hospital Bern, Bern, Switzerland; 14. CTU Berm, Bern University Hospital, Bern, Switzerland; 15. Institute of Social and Preventive Medicine, University of Bern, Bern, Switzerland

S. Windecker is a consultant for and receives fees from ABBOTT Vascular, Boston Scientific, Cordis, Medtronic, and Biosensors. F. Eberli is a speaker for Biosensors, and consultant for Cordis. P. Eerdmans is an employee of Biosensors, Europe. The remaining authors have no conflicts of interest to declare. Funding Source: The LEADERS trial was funded by Biosensors, Europe SA, Switzerland.

\section{KEYWORDS}

Biolimus eluting stent, sirolimus eluting stent, biodegradable polymer

\begin{abstract}
Aims: This study reports the 12-month clinical outcomes of the LEADERS clinical trial which compared a biolimus eluting stent with a biodegradable polymer (BES) to a sirolimus eluting stent with a durable polymer (SES).

Methods and results: The multicentre LEADERS trial employed an all-comers approach to recruit 1,707 patients who were randomised to treatment with either BES $(n=857)$ or SES $(n=850)$ in a noninferiority design. The primary clinical endpoint of this study was a composite of cardiac death, myocardial infarction and clinical-indicated target vessel revascularisation. Follow-up was obtained in $97.6 \%$ of patients. At 12 months, BES remained non-inferior compared to SES for the primary endpoint (BES 10.6\% vs. SES 12.0\%, HR:0.88, 95\% Cl:0.66-1.17, p=0.37). Rates of cardiac death (2.1\% vs. 2.7\%, HR:0.77, 95\% Cl:0.42-1.44, p=0.42), MI (5.8\% vs. 4.6\%, HR:1.27, 95\% Cl:0.84-1.94, p=0.26) and clinicallyindicated target vessel revascularisation ( $5.8 \%$ vs. 7.1\%, HR:0.82, 95\% Cl:0.56-1.19, p=0.29) were similar for BES and SES. Similarly, there was no difference in the incidence of definite stent thrombosis at 12 months.

Conclusions: These findings support the safety and efficacy of the BES stent with a biodegradable polymer at 12-month clinical follow-up, and suggest it is a suitable alternative to the SES stent with a durable polymer.
\end{abstract}

\footnotetext{
* Corresponding author: Ba583a, Thoraxcentre, Erasmus MC, 's-Gravendijkwal 230, 3015 CE Rotterdam, The Netherlands

E-mail: p.w.j.c.serruys@erasmusmc.nl
} 


\section{Introduction}

Drug eluting stents (DES) revolutionised the field of percutaneous coronary intervention (PCI) after their introduction in 2002, by significantly reducing rates of restenosis compared to bare metal stents $(\mathrm{BMS})^{1}$. In recent times there have been concerns that when compared to BMS, DES are associated with an increased risk of very late ( $>1$ year) stent thrombosis $(\mathrm{ST})^{2-4}$. The cause of this is likely to be multi-factorial, however delayed reendothelialisation plays an important role, and this in turn may be the result of a hypersensitivity reaction induced by the presence of a permanent polymer ${ }^{5,6}$.

The Biomatrix ${ }^{\mathrm{TM}}$ Flex biolimus eluting stent (BES) (Biosensors, Morges, Switzerland) elutes biolimus from a polylactic acid (PLA) biodegradable polymer applied to the stent's abluminal surface. The polymer is fully metabolised to water and carbon dioxide within six to nine months. Biolimus is a highly lipophilic sirolimus analogue ${ }^{7}$ which inhibits the mammalian target of rapamycin, and inhibits smooth muscle cell proliferation by causing the arrest of the cell cycle at $G_{0}$ with similar potency to sirolimus. Grube et al were the first to demonstrate the feasibility of a BES with a biodegradable polymer, by reporting a significantly reduced late loss and neointimal volume with BES compared with a BMS. More recently, these findings have been confirmed by other studies of biolimus eluting stents which have enrolled more diverse patient populations $^{8-12}$.

The BioMatrix ${ }^{\mathrm{TM}}$ Flex has previously been shown to be non-inferior to the Cypher $^{\circledR}$ sirolimus eluting stent (SES) (Cordis, Warren, NJ, USA) in terms of major adverse cardiovascular events (MACE) at nine months follow-up ( $9 \%$ vs. $11 \%, p$ for non-inferiority $=0.003, p$ for superiority $=0.39$ ) in the randomised LEADERS (Limus Eluted from A Durable versus ERodable Stent coating) clinical trial ${ }^{10}$. The current report presents the outcomes of the LEADERS trial at 12-month clinical follow-up, which represents a pre-specified secondary endpoint of the study.

\section{Methods}

\section{Study population}

The methods of the LEADERS trial have been published previously ${ }^{10}$. In brief the study applied an all-comers approach recruiting 1,707 patients with chronic stable coronary artery disease or acute coronary syndromes (ACS) including ST-elevation myocardial infarction (STEMI), who were eligible for enrolment if they had at $\geq 1$ lesion with diameter stenosis (DS) $\geq 50 \%$ and a reference vessel diameter (RVD) 2.25-3.5 mm. The principle exclusion criteria were: known allergy to acetylsalicylic acid, clopidogrel, heparin, stainless steel, sirolimus, biolimus or contrast material that cannot be pre-medicated, planned surgery within six months of $\mathrm{PCl}$ unless the dual anti-platelet therapy (DAPT) could be maintained throughout the peri-operative period, pregnancy, participation in another trial before reaching the primary endpoint and lastly inability to give informed consent. The study complied with the Declaration of Helsinki and was approved by all institutional ethics committees. All patients provided written, informed consent for participation in the trial.

\section{Randomisation and procedures}

Patients were randomly allocated on a 1:1 basis to treatment with either a BES or SES, and to active angiographic follow-up at nine months or clinical follow-up only on a 1:3 basis with a factorial design. BES were available in diameters of $2.25-3.5 \mathrm{~mm}$ and in lengths of 8$28 \mathrm{~mm}$, whilst SES were available in diameters of $2.25-3.5 \mathrm{~mm}$ and in lengths of $8-33 \mathrm{~mm}$. Balloon angioplasty and stent implantation were performed according to standard technique, and direct stenting was allowed. The aim was to obtain full lesion coverage with one or several stents. No mixture of DES was permitted within a given patient, unless the operator was unable to insert the study stent, in which case crossover to another device of the operator's choice was possible. Procedural anticoagulation was achieved with unfractionated heparin $5,000 \mathrm{IU}$ or $70-100 \mathrm{IU} / \mathrm{kg}$, whilst the use of glycoprotein IIb/llla inhibitors was left to the operator's discretion. Pre-procedure all patients enrolled into the study received $\geq 75 \mathrm{mg}$ of acetylsalicylic acid, and at least $300 \mathrm{mg}$ of clopidogrel. All patients were discharged on $\geq 75 \mathrm{mg}$ of acetylsalicylic acid indefinitely, and clopidogrel $75 \mathrm{mg}$ for a minimum of 12 months following the index procedure. In the case of inter-current revascularisation procedures needing stent implantation, treating cardiologists were encouraged to use study stents.

\section{Follow-up}

Adverse events were assessed in hospital, and clinical follow-up was performed at 1, 6, 9, and 12 months. Additional clinical followup is planned at yearly intervals to five years. One in four patients was asked to return for angiographic follow-up at nine months.

\section{Study endpoints}

The clinical primary endpoint of this study was MACE, defined as the composite of cardiac death, myocardial infarction (MI), and clinically-indicated target vessel revascularisation (TVR) at 12 months. Secondary endpoints were death from any cause, cardiac death, MI, any target lesion revascularisation (TLR) (both clinically and non-clinically indicated); any TVR, and ST.

A blinded independent clinical events committee adjudicated all endpoints, and independent study monitors verified all case reports from data on-site. The operators were by necessity aware of the assigned study stent during $\mathrm{PCl}$ and angiographic follow-up, but patients and staff involved in follow-up assessment were blinded to the allocated stent type. Angiography films were centrally assessed at one angiographic core laboratory (Cardialysis, Rotterdam, Netherlands) with assessors unaware of the allocated stent.

\section{Definitions}

Definitions of all endpoints are provided in full elsewhere ${ }^{10}$. MI was defined using the electrocardiographic criteria of the Minnesota code, or by a measured level of creatinine kinase (CK) two times the upper limit of normal (ULN), with either a positive concentration of CK-myoglobin fraction, or troponin I or T. Revascularisation was regarded as clinically indicated if on quantitative coronary angiography (QCA) the lumen DS of the treated lesion was $\geq 50 \%$ in the presence of ischaemic signs or symptoms, or $\geq 70 \%$ in the absence of ischaemia. TVR was defined as any repeat $\mathrm{PCl}$ or 
surgical bypass of any segment within the entire major coronary vessel proximal and distal to a target lesion, including upstream and downstream branches and the target lesion itself. TLR was defined as a repeat revascularisation due to a stenosis within the stent or within a $5 \mathrm{~mm}$ border proximal or distal to the stent. ST was defined according to the Academic Research Consortium definitions ${ }^{13}$.

\section{Statistics}

This trial was powered for non-inferiority on the primary clinical endpoint at nine months. The rationale behind this and for the sample size is reported elsewhere ${ }^{10}$. In this paper continuous variables are expressed as mean \pm standard deviation; and categorical data is presented as frequency (percentages). Patient demographic data was compared using the Student t-test, whilst $\chi^{2}$ was used for categorical data. Survival curves were constructed for time-to-event variables using Kaplan-Meier estimates, and compared by the logrank test. The Mantel-Cox model was used for the rate ratios of clinical outcome. All analyses were performed using SAS 8.02 by a dedicated statistician. All p-values and confidence intervals were twosided; $p<0.05$ was considered statistically significant.

\section{Results}

\section{Follow-up}

Figure 1 shows the clinical follow-up of patients from enrolment to 12 months, on an intention to treat basis. Overall clinical follow-up was available in 1,666 patients (97.6\%) made up of 837 of the original 857 BES patients, (97.7\%) and 829 of the original 850 SES patients (97.5\%). The reasons for incomplete follow up are shown in Figure 1.

\section{Patient population and lesion characteristics}

The baseline demographic, clinical and angiographic characteristics, have been published previously ${ }^{10}$ and are summarised in Table 1.

Procedural results and outcomes of nine month clinical and angiographic follow-up have all been presented elsewhere ${ }^{10}$. There was no significant difference in procedural characteristics between both groups. Similarly clinical outcomes at nine months in terms of

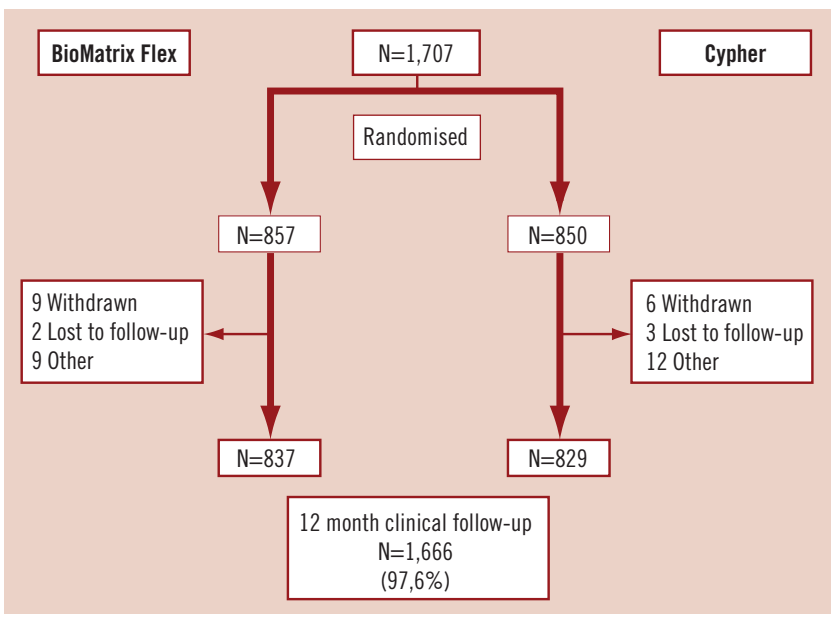

Figure 1. Flow chart of clinical follow-up of patient population.
Table 1. Baseline data.

\begin{tabular}{|c|c|c|}
\hline Variables, $\mathrm{n}(\%)$ unless stated & $\begin{array}{c}\text { BES } \\
(n=857)\end{array}$ & $\begin{array}{c}\text { SES } \\
(n=850)\end{array}$ \\
\hline \multicolumn{3}{|l|}{ Patient demographics } \\
\hline Age, years (SD) & $64.6(10.8)$ & $64.5(10.7)$ \\
\hline Male & $643(75.0 \%)$ & $634(74.6 \%)$ \\
\hline Body mass index, $\mathrm{kg} / \mathrm{m}^{2}$ & 27.6 & 27.5 \\
\hline Diabetes mellitus & $223(26.0 \%)$ & $191(22.5 \%)$ \\
\hline Hypertension & $630(73.5 \%)$ & $618(72.7 \%)$ \\
\hline Hypercholesterolaemia & $560(65.3 \%)$ & $580(68.2 \%)$ \\
\hline Current smoker & $206(24.0 \%)$ & $214(25.2 \%)$ \\
\hline Family history of CAD & $339(39.6 \%)$ & $374(44.0 \%)$ \\
\hline Previous MI & $276(32.2 \%)$ & $277(32.6 \%)$ \\
\hline Previous PCI & $312(36.4 \%)$ & $312(36.7 \%)$ \\
\hline Previous CABG & $90(10.5 \%)$ & $107(12.6 \%)$ \\
\hline Previous stroke & $40(4.7 \%)$ & $28(3.3 \%)$ \\
\hline Peripheral vascular disease & $70(8.2 \%)$ & $63(7.4 \%)$ \\
\hline Multi-vessel disease & $209(24.4 \%)$ & $176(20.7 \%)$ \\
\hline $\begin{array}{l}\text { Left ventricular ejection } \\
\text { fraction, } \%(S D)^{*}\end{array}$ & $55.9 \%(11.3)$ & $55.4 \%(12.4)$ \\
\hline SYNTAX score ${ }^{\sharp}$ & 13.2 & 13.3 \\
\hline \multicolumn{3}{|l|}{ Clinical presentation } \\
\hline Acute coronary syndrome & $470(54.8 \%)$ & $473(55.7 \%)$ \\
\hline ST-elevation MI & $135(15.8 \%)$ & $140(16.5 \%)$ \\
\hline Non ST-elevation MI & $145(16.9 \%)$ & $153(18.0 \%)$ \\
\hline Unstable angina & $190(22.2 \%)$ & $180(21.2 \%)$ \\
\hline Stable angina & $387(45.2 \%)$ & $377(44.4 \%)$ \\
\hline Silent ischaemia & $89(10.4 \%)$ & $85(10.0 \%)$ \\
\hline
\end{tabular}

Angiographic parameters

Number of lesions $>50 \%$

1256

1213

De novo lesions

$1181 / 1256(94.0 \%)$

$1126 / 1213(92.9 \%)$

Off-label use

$696(81.2 \%)$

$665(78.2 \%)$

Small-vessel disease (RVD<2.75 mm) $585(68.3 \%)$

$568(66.8 \%)$

Lesions $>20 \mathrm{~mm}$

$262(30.6 \%)$

$225(26.5 \%)$

Total occlusion

$147 / 1228(12.0 \%)$

$142 / 1194(11.9 \%)$

Bifurcation lesion

$282 / 1256(22.5 \%)$

$252 / 1213(20.8 \%)$

Severe calcification

$158 / 1210(13.1 \%)$

$166 / 1172(14.2 \%)$

Reference vessel diameter, $\mathrm{mm}(\mathrm{SD})^{ \pm} \quad 2.60(0.61) \quad 2.60(0.57)$

Minimum lumen diameter, $\mathrm{mm}(\mathrm{SD})^{\S} \quad 0.91(0.50)$

$0.95(0.52)$

Diameter stenosis, \%(SD)

$64.6 \%(17.9)$

$63.3 \%(18.2)$

* Left ventricular ejection fraction is available for $601 \mathrm{BES}$, and 607 SES patients; \# 678 patients in the BES group, and 673 in the SES group; $\neq 1,246$ assessed in the BES group, and 1,199 in the SES group; $§ 1,209$ assessed in the BES group, and 1,186 in the SES group; BES: biolimus eluting stent; SES: sirolimus eluting stent; RVD: reference vessel disease; CAD: coronary artery disease; MI: myocardial infarction; CABG: coronary artery bypass grafting

death, cardiac death, MI, clinically-indicated TLR and TVR, any TLR and TVR were also comparable for both stents. Overall the primary endpoint at nine months met the pre-specified criteria for non-inferiority (BES 9\% vs. SES 11\%, p for non-inferiority $=0.003, p$ for superiority=0.39).

Nine-month angiographic follow-up results were available in 335 patients (168 BES, and 167 SES), representing $78.5 \%$ of those allocated to angiographic follow-up. BES was non-inferior to SES for 
the angiographic outcome in-stent percentage stenosis $(20.9 \%$ vs. $23.3 \%$, p for non-inferiority=0.001). There were no significant differences in superiority testing in other angiographic parameters such as in-stent and in-segment percentage stenosis, late loss, and binary restenosis.

\section{Symptom control and medication at 12 months}

Symptomatically at 12 months $14.5 \%$ of patients (13.2\% BES, $15.7 \%$ SES) still experienced angina pectoris, or had clinical evidence of on-going silent ischaemia. In the majority of these patients the angina was stable, and at Canadian Cardiovascular Society (CCS) angina class 1 . Over $80 \%$ of patients were on a betablocker, a statin and either an angiotensin converting enzyme inhibitor or angiotension-II blocker.

\section{Clinical outcomes at 12 months}

The hierarchical and non-hierarchical events at one year clinical follow-up are shown in Table 2. At 12-month follow-up the use of BES was associated with similar rates of death and cardiac-death. Whilst patients treated with BES experienced a numerically greater number of Mls at 12-month follow-up (5.8\% vs. 4.6\%, $\mathrm{p}=0.26$ ), which was largely driven by the $0.9 \%$ higher rate of periprocedural $\mathrm{MI}$ recorded with BES, they also experienced numerically lower rates of TLR and TVR. The absolute differences between event rates observed with BES and SES were similar at nine and 12 months as can be appreciated in the Kaplan Meier survival curves (Figure 2). The rates of ST as per ARC definitions are listed in Table 3. There was no significant difference in definite, probable or possible, early or late ST between both groups. Table 4 gives a detailed description of each late ST, and indicates that eight of the nine (88.9\%) events occurred in patients still taking DAPT. Furthermore, the only ST event to occur after nine months, when the BES polymer is expected to have completely biodegraded, occurred in a patient treated with BES. This patient however was also the only patient who prematurely discontinued DAPT in view of an impending elective operation.

\section{Discussion}

This randomised prospective study has confirmed the comparable clinical outcomes at one year follow-up, in an 'all-comers' population, of the BES with a biodegradable polymer when compared to the sirolimus eluting stent with a durable polymer.

Early trials of new DES recruited patients with simple, de novo lesions, and although important, their results are not applicable to the $60-70 \%$ of today's $\mathrm{PCl}$ patients who receive DES for 'off-label' indications. ${ }^{14}$ Compared to 'on-label' use, the use of DES for 'offlabel' indications is associated with poorer outcomes and a higher risk of ST ${ }^{14,15}$. The current study had an 'all-comers' design, such that over half of the patients enrolled had an acute coronary syndrome (unstable angina, Non-ST elevation MI, ST-elevation MI), and over three-quarters of patients had stenting for an 'off-label' indication. Therefore, it comes as no surprise that the overall event rates reported in this study are somewhat higher than those observed in earlier trials of new DESs ${ }^{16}$. Notwithstanding this, these results can be regarded as being more applicable to routine clinical practice.
Table 2. Clinical outcomes.

\begin{tabular}{|c|c|c|c|c|}
\hline $\begin{array}{l}\text { 12-month outcomes, } \\
\text { n (\%) }\end{array}$ & $\begin{array}{c}\text { BES } \\
(n=857)\end{array}$ & $\begin{array}{c}\text { SES } \\
(n=850)\end{array}$ & $\begin{array}{l}\text { Relative risk } \\
\text { [95\% CI] }\end{array}$ & P Value \\
\hline \multicolumn{5}{|l|}{ Hierarchical } \\
\hline Cardiac death & $18(2.1 \%)$ & $23(2.7 \%)$ & $0.77[0.42-1.44]$ & 0.42 \\
\hline MI without cardiac death & $41(4.8 \%)$ & $35(4.1 \%)$ & & \\
\hline Q-wave & $4(0.5 \%)$ & $6(0.7 \%)$ & & \\
\hline Non- $Q$ wave & $37(4.3 \%)$ & $29(3.4 \%)$ & & \\
\hline $\begin{array}{l}\text { Clinically indicated TVR } \\
\text { without death or MI }\end{array}$ & $32(3.7 \%)$ & $44(5.2 \%)$ & & \\
\hline Surgical & $5(0.6 \%)$ & $5(0.6 \%)$ & & \\
\hline Percutaneous & $27(3.2 \%)$ & $39(4.6 \%)$ & & \\
\hline Any MACE & $91(10.6 \%)$ & $102(12.0 \%)$ & $0.88[0.66-1.17]$ & 0.37 \\
\hline \multicolumn{5}{|l|}{ Non-hierarchical } \\
\hline Death & $27(3.2 \%)$ & $28(3.3 \%)$ & $0.95[0.56-1.62]$ & 0.86 \\
\hline Cardiac death & $18(2.1 \%)$ & $23(2.7 \%)$ & $0.77[0.42-1.44]$ & 0.42 \\
\hline MI & $50(5.8 \%)$ & $39(4.6 \%)$ & $1.27[0.84-1.94]$ & 0.26 \\
\hline Q-wave & $4(0.5 \%)$ & $7(0.8 \%)$ & $0.56[0.17-1.93]$ & 0.36 \\
\hline Non-Q-wave & $46(5.4 \%)$ & $33(3.9 \%)$ & $1.39[0.89-2.17]$ & 0.15 \\
\hline Clinically indicated TLR & $44(5.1 \%)$ & $49(5.8 \%)$ & $0.88[0.59-1.33]$ & 0.55 \\
\hline Percutaneous & $42(4.9 \%)$ & $46(5.4 \%)$ & $0.90[0.59-1.37]$ & 0.62 \\
\hline Surgical & $5(0.6 \%)$ & $5(0.6 \%)$ & $0.99[0.29-3.41]$ & 0.98 \\
\hline All TLR & $56(6.5 \%)$ & $63(7.4 \%)$ & $0.87[0.61-1.25]$ & 0.46 \\
\hline Percutaneous & $52(6.1 \%)$ & $59(6.9 \%)$ & $0.87[0.60-1.26]$ & 0.46 \\
\hline Surgical & $8(0.9 \%)$ & $8(0.9 \%)$ & $0.99[0.37-2.63]$ & 0.98 \\
\hline Clinically indicated TVR & $50(5.8 \%)$ & $60(7.1 \%)$ & $0.82[0.56-1.19]$ & 0.29 \\
\hline Percutaneous & $47(5.5 \%)$ & $56(6.6 \%)$ & $0.82[0.56-1.21]$ & 0.33 \\
\hline Surgical & $6(0.7 \%)$ & $7(0.8 \%)$ & $0.85[0.28-2.52]$ & 0.76 \\
\hline All TVR & $67(7.8 \%)$ & $84(9.9 \%)$ & $0.78[0.56-1.07]$ & 0.13 \\
\hline Percutaneous & $60(7.0 \%)$ & $75(8.8 \%)$ & $0.78[0.56-1.10]$ & 0.16 \\
\hline Surgical & $11(1.3 \%)$ & $13(1.5 \%)$ & $0.83[0.37-1.86]$ & 0.66 \\
\hline
\end{tabular}

BES: biolimus eluting stent; SES: sirolimus eluting stent; CI: confidence interval; MI: myocardial infarction; TVR: target vessel revascularisation; MACE: major adverse cardiovascular events; TLR: target lesion revascularisation

The formal comparison of outcomes in patients treated for 'on-label' versus 'off-label' indications is not yet available. However post hoc sub-group analysis of diabetic patients indicates significantly reduced in-stent restenosis with the use of BES compared to SES at nine months angiographic follow-up $(21.79 \% \pm 19.42$ vs. $33.57 \% \pm 25.42$, $\mathrm{p}=0.01$ ), whilst at 12 -month clinical follow-up, insulin treated diabetics treated with BES had a significantly reduced rate of mortality $(p<0.01)^{17}$. Overall no significant difference in clinical outcomes were observed between patients with ACS treated with either stent, however, in patients with STEMI, the use of BES was associated with a significantly lower rate of 12 month cardiac death $(p=0.04)$ and MACE $(p=0.02)$ compared with SES. This was largely driven by reduction in sub-acute ST and TVR within the first 30 days $^{18}$. Other available analyses indicates similar performance between both stents in the management of patients with bifurcation lesions ${ }^{19}$, lesions in vessels less than $2.75 \mathrm{~mm}$ in diameter ${ }^{20}$, and lesions longer than $20 \mathrm{~mm}^{21}$. The higher rate of $\mathrm{MI}$ noted with BES was largely driven by periprocedural events, as opposed to spontaneous Mls. Post hoc analysis has demonstrated over half of these periprocedural events 
A

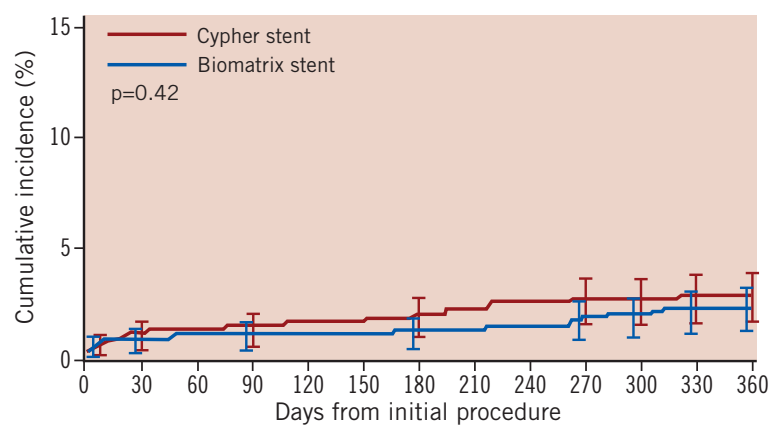

B

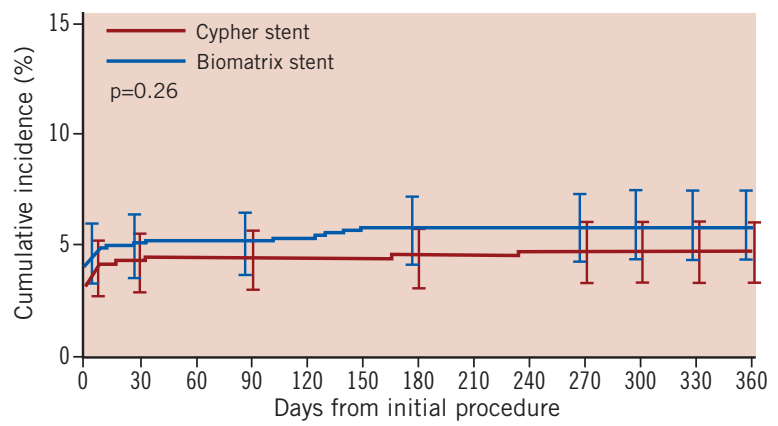

C

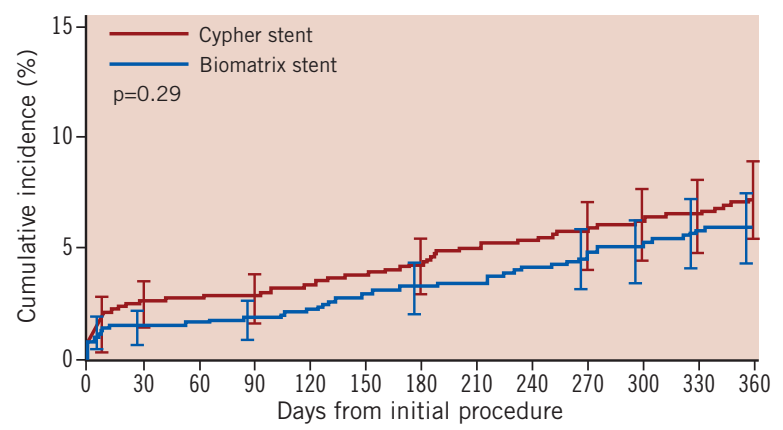

D

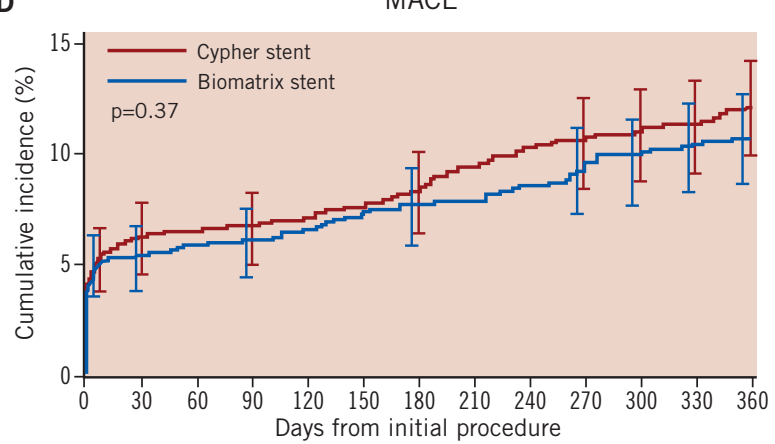

Figure 2. Kaplan Meier event curves at 12 months for $(A)$ cardiac death, (B) myocardial infarction, (C) clinically-indicated target vessel revascularisation and $(D)$ major adverse cardiovascular events.

occurred in patients who had at least one bifurcation lesion, with procedural factors, i.e., more frequent pre-dilatation suggested as a possible cause ${ }^{19}$. Furthermore these periprocedural Mls did not have any effect on cardiac death. At 30 days, 42 patients experienced an $\mathrm{MI}$, and only three patients experienced a cardiac death. Currently the significance of a periprocedural MI has not been clearly established;
Table 3. Stent thrombosis events by ARC definitions.

\begin{tabular}{lrrr} 
& $\begin{array}{c}\text { BES } \\
(\mathbf{n}=857)\end{array}$ & $\begin{array}{c}\text { SES } \\
(\mathbf{n}=850)\end{array}$ & P Value \\
\hline Definite stent thrombosis & & & \\
$\quad$ Early stent thrombosis [0-30 days] & $14(1.6 \%)$ & $14(1.6 \%)$ & 0.98 \\
Late stent thrombosis [30-360 days] & $3(0.4 \%)$ & $4(0.5 \%)$ & 0.69 \\
Total stent thrombosis [0-360 days] & $17(2.0 \%)$ & $17(2.0 \%)^{*}$ & 0.98 \\
Probable stent thrombosis & & & \\
$\quad$ Early stent thrombosis [0-30 days] & $5(0.6 \%)$ & $2(0.2 \%)$ & 0.26 \\
Late stent thrombosis [30-360 days] & $2(0.2 \%)$ & $0(0.0 \%)$ & 0.16 \\
Total stent thrombosis [0-360 days] & $7(0.8 \%)$ & $2(0.2 \%)$ & 0.10 \\
Possible stent thrombosis & & & \\
Early stent thrombosis [0-30 days] & $0(0.0 \%)$ & $0(0.0 \%)$ & - \\
Late stent thrombosis [30-360 days] & $7(0.8 \%)$ & $9(1.1 \%)$ & 0.60 \\
Total stent thrombosis [0-360 days] & $7(0.8 \%)$ & $9(1.1 \%)$ & 0.60 \\
Definite or probable stent thrombosis & & & \\
Early stent thrombosis [0-30 days] & $18(2.1 \%)$ & $16(1.9 \%)$ & 0.75 \\
Late stent thrombosis [30-360 days] & $5(0.6 \%)$ & $4(0.5 \%)$ & 0.75 \\
Total stent thrombosis [0-360 days] & $23(2.7 \%)$ & $19(2.2 \%)$ & 0.55 \\
\hline
\end{tabular}

* Excludes one definite secondary stent thrombosis, which occurred in a patient at 60 days, who had already experienced a stent thrombosis at three days; BES: biolimus eluting stent; SES: sirolimus eluting stent; CI: confidence interval

recent studies demonstrate that rises in cardiac enzymes post- $\mathrm{PCl}$ are common and may predict short-term prognosis ${ }^{22}$, but do not influence long-term prognosis ${ }^{22}$, especially if the procedure is successful ${ }^{23}$.

$\mathrm{ST}$ is one of the most prominent concerns with the widespread use of DES in daily clinically practice ${ }^{1-4}$. The occurrence of ST remains largely unpredictable and no specific causative factor has been identified. One area where concern has been focused is the potential of durable, or permanent polymers to precipitate very late ST. This may be the result of inducing a hypersensitivity reaction ${ }^{5,6}$, however recent histopathological studies have also shown that durable polymers can also cause localised vascular inflammation, hyper-eosinophilia, thrombogenic reactions, and apoptosis of smooth muscle cells, all of which may precipitate ST ${ }^{24-26}$. Specifically the non-erodible polymers poly (ethylene co-vinyl acetate) and poly (n-butyl methacrylate) found on the first generation Cypher ${ }^{\circledR}$ SES have been shown to induce hypersensitivity reactions in animal models and humans ${ }^{27,28}$. One recent advance in polymer technology has been the development of PLA biodegradable polymers, as found on the BioMatrix BES stent used in this study. This polymer is located only on the abluminal surface of the stent, which not only allows for better targeted drug release, but also reduces systemic exposure to both the polymer and biolimus. Furthermore, the polymer is co-released with biolimus, and biodegrades to carbon dioxide and water, such that only a stainless steel stent, which is free of any primer polymer, remains after 6-9 months of stent deployment. In theory this should potentially reduce the risk of precipitating late and very late ST.

The similar rates of ST observed in the current study however should not be considered to indicate the lack of benefit of a biodegradable polymer. This is primarily because the current study is underpowered to detect differences in ST. In reality a considerably larger study population, followed long term will be required to enable definitive conclusions to be drawn about whether a biodegradable polymer will impact significantly on rates of late/very late ST. 
Table 4. Detailed description of late stent thrombosis events.

\begin{tabular}{|c|c|c|c|c|c|c|}
\hline $\begin{array}{l}\text { Days post } \\
\text { index } \mathrm{PCI}\end{array}$ & Stent & $\begin{array}{c}\text { Type of stent } \\
\text { thrombosis }\end{array}$ & Presentation & Location & Outcome & DAPT at time of ST \\
\hline 34 & BES & Probable & $\begin{array}{c}\text { Target vessel related } \\
\text { Q-wave MI }\end{array}$ & LAD\# & $\begin{array}{l}\text { No intervention performed } \\
\text { Stable on discharge }\end{array}$ & Yes \\
\hline 60 & SES & Definite & Unstable angina & LAD & Target lesion CABG (day 99) & Yes* \\
\hline 63 & SES & Definite & Unstable angina & SVG & $\begin{array}{l}\text { Unable to open occluded } \\
\text { SVG Stable on discharge }\end{array}$ & Yes \\
\hline 89 & BES & Definite & Stable angina & Circumflex & $\begin{array}{l}\text { Unable to open occluded } \\
\text { vessel Stable on discharge }\end{array}$ & Yes \\
\hline 99 & SES & Definite & $\begin{array}{c}\text { Target vessel related } \\
\text { Q-wave MI }\end{array}$ & RCA & Clinically driven TLR (day 99) & Yes \\
\hline 107 & BES & Definite & Stable angina & 1st diagonal & Clinically driven TLR (day 107) & Yes \\
\hline 166 & BES & Probable & Target vessel related MI & SVG\# & Cardiac death (day 167) & Yes \\
\hline 237 & SES & Definite & $\begin{array}{l}\text { Non- } Q \text {-wave } \\
\text { target vessel }\end{array}$ & RCA & $\begin{array}{l}\text { Unable to open occluded } \\
\text { vessel Stable on discharge }\end{array}$ & Yes \\
\hline 350 & BES & Definite & $\begin{array}{l}\text { Post-operative } \\
\text { angina pectoris }\end{array}$ & LAD & $\begin{array}{c}\text { Clinically driven TLR } \\
\text { (day 350) }\end{array}$ & $\begin{array}{l}\text { No (stopped } 11 \text { days } \\
\text { prior for operation) }\end{array}$ \\
\hline
\end{tabular}

* Patient experienced an early definite ST as well; \# Location suspected, but not confirmed, as no angiography performed; BES: biolimus eluting stent; SES: sirolimus eluting stent; PCI: percutaneous coronary intervention; DAPT: dual anti-platelet therapy; MI: myocardial infarction; TLR: target lesion revascularisation; RCA: right coronary artery; LAD: left anterior descending artery; SVG: saphenous vein graft; CABG: coronary artery bypass grafting

The limited long-term data that is available on metallic stents with biodegradable polymers show promising results, and suggests, as indicated in this study, the absence of significant repeat revascularisations or clinical events following the complete biodegradation of the polymer. The Excel stent (JW Medical Systems, China) is a stainless steel stent, coated with sirolimus and a PLA biodegradable polymer, which completes degradation in 6-9 months. A registry of over 2,000 patients has recently shown at 18 -month follow-up, a rate of MACE of $3.1 \%$, and despite $80.5 \%$ of patients discontinuing clopidogrel at six months, a rate of ST of $0.87 \%{ }^{29}$. The longest follow-up data is available from the Nobori phase I trial which randomised the Nobori $^{\mathrm{TM}}$ (Terumo, Japan) BES with a PLA biodegradable polymer to the TAXUS ${ }^{\circledR}$ Express $^{2}$ (Boston Scientific, Natick, MA, USA) paclitaxel eluting stent in 120 patients. After biodegradation of the polymer at 6-9 months there were no ST events, TVR or target vessel failures (cardiac death, MI-target vessel related, clinically driven TVR) in those treated with the Nobori stent, however the population enrolled was considerably less complex than the current study ${ }^{30}$.

This limited data set indicates the importance of the long term follow-up results of the present study, which should help in establishing whether biodegradable polymers will be vital components of future DES.

\section{Limitations}

One limitation with the results of the current study are their reproducibility when considering that the $\mathrm{PCl}$ procedures were performed by experienced operators, in high volume centres throughout Europe.

\section{Conclusions}

The present report demonstrates the safety and efficacy during 12-month clinical follow-up of a biolimus eluting stent with a biodegradable polymer, and indicates that this stent is a suitable alternative to a sirolimus eluting stent with a durable polymer, in patients with simple and complex coronary artery disease.

\section{References}

1. Stettler C, Wandel S, Allemann S, Kastrati A, Morice MC, Schomig A, Pfisterer ME, Stone GW, Leon MB, de Lezo JS, Goy JJ, Park SJ, Sabate M, Suttorp MJ, Kelbaek H, Spaulding C, Menichelli M, Vermeersch $P$, Dirksen MT, Cervinka P, Petronio AS, Nordmann AJ, Diem P, Meier B, Zwahlen M, Reichenbach S, Trelle S, Windecker S, Juni P. Outcomes associated with drug-eluting and bare-metal stents: a collaborative network meta-analysis. Lancet. 2007;370:937-48.

2. Lagerqvist B, James SK, Stenestrand U, Lindback J, Nilsson T, Wallentin L, the SSG. Long-Term Outcomes with Drug-Eluting Stents versus Bare-Metal Stents in Sweden. N Engl J Med. 2007;356:1009-1019.

3. Camenzind E, Steg PG, Wijns W. Stent thrombosis late after implantation of first-generation drug-eluting stents: a cause for concern. Circulation. 2007;115:1440-55; discussion 1455.

4. Nordmann AJ, Briel M, Bucher HC. Mortality in randomized controlled trials comparing drug-eluting vs. bare metal stents in coronary artery disease: a meta-analysis. Eur Heart J. 2006;27:2784-814.

5. van der Giessen WJ, Lincoff AM, Schwartz RS, van Beusekom HM, Serruys PW, Holmes DR, Jr., Ellis SG, Topol EJ. Marked inflammatory sequelae to implantation of biodegradable and nonbiodegradable polymers in porcine coronary arteries. Circulation. 1996;94:1690-7.

6. Joner M, Finn AV, Farb A, Mont EK, Kolodgie FD, Ladich E, Kutys R, Skorija K, Gold HK, Virmani R. Pathology of drug-eluting stents in humans: delayed healing and late thrombotic risk. J Am Coll Cardiol. 2006;48:193-202.

7. Grube E, Buellesfeld L. BioMatrix Biolimus A9-eluting coronary stent: a next-generation drug-eluting stent for coronary artery disease. Expert Rev Med Devices. 2006;3:731-41.

8. Chevalier B, Serruys PW, Silber S, Garcia E, Suryapranata H, Hauptmann K, Wijns W, Schuler G, Fath-Ordoubadi F, Worthley S. Randomised comparison of Nobori ${ }^{\mathrm{TM}}$, biolimus A 9-eluting coronary stent with a Taxus ${ }^{\circledR}$, paclitaxel-eluting coronary stent in patients with stenosis in native coronary arteries: the Nobori 1 trial. Eurolntervention. 2007;2:426-434.

9. Chevalier B, Silber S, Park S-J, Garcia E, Schuler G, Suryapranata H, Koolen J, Hauptmann KE, Wijns W, Morice M-C, Carrie D, van Es G-A, Nagai H, Detiege D, Paunovic D, Serruys PW, for the 
NCl. Randomized Comparison of the Nobori Biolimus A9-Eluting Coronary Stent With the Taxus Liberte Paclitaxel-Eluting Coronary Stent in Patients With Stenosis in Native Coronary Arteries: The NOBORI 1 Trial-Phase 2. Circ Cardiovasc Intervent. 2009;2:188-195.

10. Windecker S, Serruys PW, Wandel S, Buszman P, Trznadel S, Linke A, Lenk K, Ischinger T, Klauss V, Eberli F, Corti R, Wijns W, Morice MC, di Mario C, Davies S, van Geuns RJ, Eerdmans P, van Es GA, Meier B, Juni P. Biolimus-eluting stent with biodegradable polymer versus sirolimus-eluting stent with durable polymer for coronary revascularisation (LEADERS): a randomised non-inferiority trial. Lancet. 2008;372:1163-73.

11. Verheye S, Agostoni P, Dubois CL, Dens J, Ormiston J, Worthley S, Trauthen B, Hasegawa T, Koo B-K, Fitzgerald PJ, Mehran R, Lansky AJ. 9-month clinical, angiographic, and intravascular ultrasound results of a prospective evaluation of the Axxess self-expanding biolimus A9-eluting stent in coronary bifurcation lesions: the DIVERGE (Drug-Eluting Stent Intervention for Treating Side Branches Effectively) study. J Am Coll Cardiol. 2009;53:1031-9.

12. Grube E. Custom clinical programme. EuroPCR May 19th-22nd 2008; Barcelona. [online] Available www.europcronline.com/fo/lecture/ view_slide.php?idCongres=4\&id=5514 [Accessed June 18th 2009].

13. Cutlip DE, Windecker S, Mehran R, Boam A, Cohen DJ, van Es GA, Steg PG, Morel MA, Mauri L, Vranckx P, McFadden E, Lansky A, Hamon M, Krucoff MW, Serruys PW. Clinical end points in coronary stent trials: a case for standardized definitions. Circulation. 2007;115:2344-51.

14. Kirtane AJ, Gupta A, lyengar S, Moses JW, Leon MB, Applegate R, Brodie B, Hannan E, Harjai K, Jensen LO, Park SJ, Perry R, Racz M, Saia F, Tu JV, Waksman R, Lansky AJ, Mehran R, Stone GW. Safety and efficacy of drug-eluting and bare metal stents: comprehensive metaanalysis of randomized trials and observational studies. Circulation. 2009;119:3198-206.

15. Lasala JM, Cox DA, Dobies D, Baran K, Bachinsky WB, Rogers EW, Breall JA, Lewis DH, Song A, Starzyk RM, Mascioli SR, Dawkins KD, Baim DS, for the AaAPP. Drug-Eluting Stent Thrombosis in Routine Clinical Practice: Two-Year Outcomes and Predictors From the TAXUS ARRIVE Registries. Circ Cardiovasc Intervent. 2009;2:285-293.

16. Morice MC, Serruys PW, Sousa JE, Fajadet J, Ban Hayashi E, Perin M, Colombo A, Schuler G, Barragan P, Guagliumi G, Molnar F, Falotico R. A randomized comparison of a sirolimus-eluting stent with a standard stent for coronary revascularization. N Engl J Med. 2002;346:1773-80.

17. Linke $A$, Lenk K, Serruys $P$, van Es GA, Buszman $P$, Ischinger $T$, Klauss V, Eberli F, Wijns W, Morice MC, di Mario C, Juni P, Schuler G, Windecker S. Impact of diabetes on angiographic and clinical outcomes of revascularization with biolimus-eluting stent with biodegradable polymer and sirolimus-eluting stent with durable polymer. LEADERS trial substudy. Poster presentation Transcatheter Therapeutics, San Francisco, September 20th 2009.

18. Buszman P. Outcomes with drug-eluting stents in acute coronary syndromes. A substudy from the LEADERS trial. Presentation EuroPCR, Barcelona, 20th May 2009.

19. Garg S. The outcome of bifurcation lesion stenting using a biolimus eluting stent with a biodegradable polymer compared to a sirolimus eluting stent with a durable polymer. Presentation EuroPCR, 20th May 2009. Online www.europcronline.com/fo/lecture/view_slide.php?idCongres $=5 \&$ id $=7856$. Accessed July 14th 2009 .
20. Wykrzykowska J, Serruys P, Onuma Y, De Vries T, van Es GA, Buszman P, Linke A, Ischinger T, Klauss V, Corti R, Eberli F, Wijns W, Morice MC, Dimario C, van Geuns RJ, Juni P, Windecker S. Impact of vessel size on angiographic and clinical outcomes of revascularization with biolimus-eluting stent with biodegradable polymer and sirolimus-eluting stent with durable polymer. LEADERS trial substudy. JACC CardiovasC Interv. 2009;2:861-870.

21. Wykrzykowska JJ, Raber L, de Vries T, Bressers M, Buszman P, Linke A, Ischinger T, Klauss V, Eberli F, Corti R, Wijns W, Morice MC, di Mario C, Regar E, Juni P, Windecker S, Serruys PW. Biolimus-eluting biodegradable polymer versus sirolimus-eluting permanent polymer stent performance in long lesions: results from the LEADERS multicentre trial substudy. Eurolntervention. 2009;5:310-7.

22. Prasad A, Rihal CS, Lennon RJ, Singh M, Jaffe AS, Holmes Jr DR. Significance of periprocedural myonecrosis on outcomes after percutaneous coronary intervention: an analysis of preintervention and postintervention troponin T levels in 5487 patients. Circulation: Cardiovascular Interventions. 2008;1:10.

23. Jeremias A, Baim DS, Ho KK, Chauhan M, Carrozza JP, Jr., Cohen DJ, Popma JJ, Kuntz RE, Cutlip DE. Differential mortality risk of postprocedural creatine kinase-MB elevation following successful versus unsuccessful stent procedures. J Am Coll Cardiol. 2004;44:1210-4.

24. Virmani R, Liistro F, Stankovic G, Di Mario C, Montorfano M, Farb A, Kolodgie FD, Colombo A. Mechanism of Late In-Stent Restenosis After Implantation of a Paclitaxel Derivate-Eluting Polymer Stent System in Humans. Circulation. 2002;106:2649-2651.

25. Virmani R, Guagliumi G, Farb A, Musumeci G, Grieco N, Motta T, Mihalcsik L, Tespili M, Valsecchi O, Kolodgie FD. Localized hypersensitivity and late coronary thrombosis secondary to a sirolimus-eluting stent: should we be cautious? Circulation. 2004;109:701-5.

26. Nebeker JR, Virmani R, Bennett CL, Hoffman JM, Samore MH, Alvarez J, Davidson CJ, McKoy JM, Raisch DW, Whisenant BK, Yarnold PR, Belknap SM, West DP, Gage JE, Morse RE, Gligoric G, Davidson L, Feldman MD. Hypersensitivity cases associated with drugeluting coronary stents: a review of available cases from the Research on Adverse Drug Events and Reports (RADAR) project. J Am Coll Cardiol. 2006; 47:175-81.

27. Cook S, Ladich E, Nakazawa G, Eshtehardi P, Neidhart M, Vogel R, Togni M, Wenaweser P, Billinger M, Seiler C, Gay S, Meier B, Pichler WJ, Juni P, Virmani R, Windecker S. Correlation of intravascular ultrasound findings with histopathological analysis of thrombus aspirates in patients with very late drug-eluting stent thrombosis. Circulation. 2009;120:391-9.

28. Nakazawa G, Ladich E, Finn AV, Virmani R. Pathophysiology of vascular healing and stent mediated arterial injury. Eurointervention. 2008;4 Suppl C:C7-10.

29. Han $Y$, Jing $Q$, Xu B, Yang L, Liu H, Shang X, Jiang T, Li Z, Zhang H, Li H, Qiu J, Liu Y, Li Y, Chen X, Gao R, for the Cl. Safety and Efficacy of Biodegradable Polymer-Coated Sirolimus-Eluting Stents in "Real-World" Practice: 18-Month Clinical and 9-Month Angiographic Outcomes. J Am Coll Cardiol Intv. 2009;2:303-309.

30. Chevalier B. Nobori I - Long term results. Two years Phase 1, One year Phase 2. EuroPCR, Barcelona 2008. [Online] Available: www.europcronline.com/fo/lecture/view_slide. php?idCongres $=4 \& i d=4540$. Accessed August 1st 2009. 